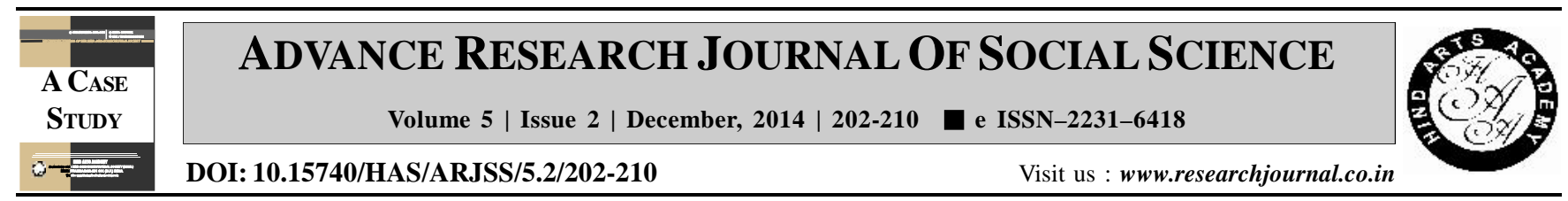

\title{
Emotional intelligence of dual-earner couples
}

A.S. Jakkaraddi*, V.S. Yadav ${ }^{1}$ and P.B. Khadi

Department of Human Development and Family Studies, College of Rural Home Science, University of Agricultural Sciences, DHARWAD (KARNATAKA) INDIA (Email: angadiarati@gmail.com, pkhadi@gmail.com)

${ }^{1}$ Department of Agricultural Extension, University of Agricultural Sciences, DHARWAD (KARNATAKA) INDIA

(Email: yadav.vithalrao@gmail.com)

\section{ARTICLE INFO :}

Received : 10.05 .2014

Accepted : 15.11 .2014

\section{KEY WORDS :}

Emotional intelligence, Dual earners, Individual skills

\section{HOW TO CITE THIS ARTICLE :}

Jakkaraddi, A.S., Yadav, V.S. and Khadi, P.B. (2014). Emotional intelligence of dual-earner couples. Adv. Res. J. Soc. Sci., 5 (2) : 202-210.

*Author for correspondence

\begin{abstract}
The present study aims to understand the level of emotional intelligence among dual-earner couples. The sample was selected from both public and private sectors using the snow-ball technique from Dharwad city. The sample comprised of 155 dual-earner couples. Inclusion criteria for dual-earner couple was that one of the spouses should be a primary school teacher with a minimum of five years experience, having at least one child and married for at least five years. Emotional intelligence questionnaire developed by Dulewicz and Higgs (2001) was used. The results revealed that 10.9 per cent of the couples had lower emotional intelligence, 7.4 per cent had average emotional intelligence, and 82.25 per cent had developed high status of emotional intelligence. The results revealed that there was a significant association of gender on three components of emotional intelligence i.e., emotional resilience, motivation and intuitiveness. More number of females had developed higher score on these three components than males.
\end{abstract}

